\title{
AZ EGYENESFOGÚ METSZŐKERÉK GEOMETRIAI MODELL SZÁMÍTÓGÉPES KIÉRTÉKELÉSÉNEK HIBÁI
}

\section{THE NUMERICAL EVALUATION ERRORS OF THE GEOMETRIC MODEL OF THE STRAIGHT TEETHED SHAPER CUTTER}

\author{
Máté Márton, ${ }^{1}$ Hollanda Dénes ${ }^{2}$ \\ Sapientia Erdélyi Magyar Tudományegyetem, Marosvásárhelyi Kar, Gépészmérnöki Tanszék, \\ Marosvásárhely, Románia \\ ${ }^{1}$ mmate@ms.sapientia.ro \\ ${ }^{2}$ hollanda@ms.sapientia.ro
}

\begin{abstract}
It is well known that straight teethed shaper cutters present a theoretical profile error. The side edges are situated on a common conical rack face with the result that they and their projection in the generating plane can't be involute curves. The optimization of the cutter requires such a correlation of the edge defining parameters that the potential theoretical profile error is kept to the minimum possible. Thus the relevance of the edge equations is of great importance. This paper deals with the analysis of the edge equations, presenting two different forms of it. The comparison between the two different forms is realized by applying the numerical evaluation, by substitution of the edge point coordinates in the implicit equations of the originating surfaces. The obtained results present a difference of magnitude 10-E3. Finally, it can be concluded that the two forms of the edge equations cannot be used randomly but only in correlation with the goal proposed by the running application.
\end{abstract}

Keywords: shaper cutter, model, edge, profile error, computing error.

\section{Összefoglalás}

Az egyenesfogú metszőkerék közismerten elméleti profilhibával rendelkezik. Ez a klasszikus, léccel való lefejtés következménye. A szerszám optimalizálásakor az élalakot meghatározó paramétereket kell oly módon összehangolni, hogy a lehető legkisebb elméleti profilhiba keletkezzen. Ezért az él egyenletei igen fontos szerepet töltenek be. Jelen dolgozat az egyenesfogú metszőkerék élegyenleteinek két különböző alakját mutatja be. Ezek összehasonlítását numerikus vizsgálattal végeztük el, úgy, hogy az élpontok koordinátáit visszahelyettesítettük az éleket meghatározó felületek implicit egyenleteibe. A különbségek kiértékelése során ezres nagyságrendnyi eltérést veszünk észre, de a hiba abszolút értéke 10E-12-10E-16. Következtetésként kijelenthetjük, hogy az egyes egyenletalakok használata nem történhet véletlenszerüen, hanem az alkalmazásban kijelentett céltól függően kell ezeket alkalmazni.

Kulcsszavak: metszőkerék, modell, él, profilhiba, számítási hiba.

\section{Az egyenesfogú metszőkerék geomet- riai modellje}

Az egyenesfogú metszőkerék geometriai modellje a klasszikus, léccel való generálás elméletén alapul [1, 2, 3, 4]. A szerszámléc egyenes profilú, $\alpha_{0 s}$ kapcsolószögü, mely lefejtés közben a metszőkeréken ennek alapsíkjától a felső határsíkig lineárisan csökkenő profileltolást hoz létre. A metszőkerék fogát ennek következtében az alsó és a felső határ-homloksík közé zárt két, egymással 
szembeforduló csavarevolvens-felületdarab és egy $a_{\mathrm{v}}$ félkúpszögü, az $R_{a}$ sugarú fejkörre illesztett egyenes körkúp-felületszelet határoz meg. A csavarevolvens-felület osztóhengeri csavarvonalának $\beta_{0}$ dőlésszögét a szakirodalomban egyszerü geometriai számítások alapján levezethető [3, 4]

$$
\operatorname{tg} \beta_{0}=\operatorname{tg} \alpha_{V} \operatorname{tg} \alpha_{0 s}
$$

képlettel számítják. Figyelembe véve az osztókör és az alapkör sugarainak kapcsolatát, az alapköri csavarvonal dőlésszögét a

$$
\operatorname{tg} \beta_{b}=\operatorname{tg} \alpha_{V} \sin \alpha_{0 s}
$$

összefüggés adja meg.

A $z_{s}$ fogszám és a $\xi_{s}$ szerszámprofil-eltolás és a modul függvényében, az evolvenstrigonometria második alapegyenletének használatával [5] kapjuk az alapsíkbeli evolvensgörbe alapköri pontjának polársugara és az $O_{s} x_{s}$ tengely által bezárt $\eta$ helyzetszög értékét:

$$
\eta=\frac{\pi}{2 z_{s}}+2 \frac{\xi_{s}}{z_{s}} \operatorname{tg} \alpha_{0 s}+\operatorname{inv} \alpha_{0 s}
$$

Megjegyezzük, hogy az $O_{s} x_{s}$ tengely a szerszámfog alapszelvényének szimmetriatengelye.

\subsection{Az oldal-hátfelület}

Az oldal-hátfelület egyenleteit az 1. ábra alapján vezetjük le. Az evolvens-csavarfelület képzésére több technológiai módszer létezik [4, 6, 7, 8], viszont a kinematikai geometria két lehetőséget kínál:

- az alapsíkbeli evolvensgörbére csavartranszformációt alkalmazunk, vagy

- az alaphengeren legördítünk egy [S] síkot, mely ennek tengelyével $\beta_{b}$ szöget bezáró egyenest tartalmaz.

Az első esetben, az 1. ábrán látható jelölésekkel, az evolvensgörbe, vagyis a generáló görbe egyenletei a következők [9]:

$$
\left\{\begin{array}{l}
x(u)=R_{b}(\cos (u-\eta)+u \sin (u-\eta)) \\
y(u)=R_{b}(\sin (u-\eta)-u \cos (u-\eta))
\end{array}\right.
$$

Ha erre $p=R_{0} / \cos \beta_{0}=R_{b} \cos \beta_{b}$ paraméterü, $O z_{s}$ tengelyü, $p_{w}$ értékű csavartranszformációt alkalmazunk, akkor a következő egyenletekhez jutunk [9]:

$$
\left\{\begin{array}{l}
x_{s}(u, w)=R_{b}(\cos (u-\eta+w)+u \sin (u-\eta+w)) \\
y_{s}(u, w)=R_{b}(\sin (u-\eta+w)-u \cos (u-\eta+w)) \\
z_{s}(u, w)=p w
\end{array}\right.
$$

$\mathrm{Az}$ 1. ábrán szemléltetett geometriai elemek vizsgálata alapján azonnal felírhatók az alábbi összefüggések:

$$
\begin{aligned}
\mathbf{O}_{\mathbf{s}} \mathbf{M} & =\mathbf{O}_{\mathbf{s}} \mathbf{P}+\mathbf{P Q}+\mathbf{Q M} \\
P Q & =p \varphi \\
Q M & =\lambda
\end{aligned}
$$

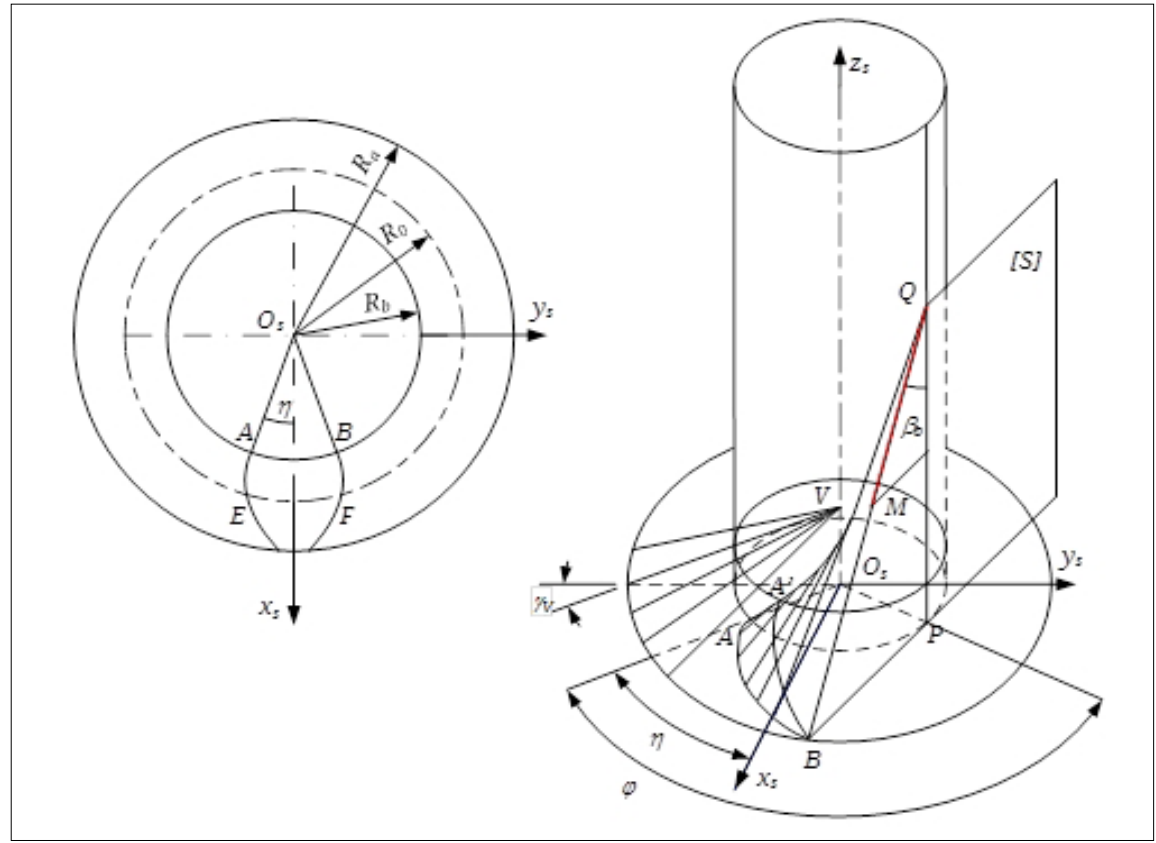

1. ábra. A csavarevolvens lefejtésének geometriai összefüggései 
A vektoregyenlet mátrixos alakja a következő:

$$
\left(\begin{array}{l}
x_{s} \\
y_{s} \\
z_{s}
\end{array}\right)=\left(\begin{array}{c}
R_{b} \cos (\varphi-\eta) \\
R_{b} \sin (\varphi-\eta) \\
0
\end{array}\right)+\left(\begin{array}{c}
0 \\
0 \\
p \varphi
\end{array}\right)+\left(\begin{array}{c}
\lambda \sin \beta_{b} \sin (\varphi-\eta) \\
-\lambda \sin \beta_{b} \cos (\varphi-\eta) \\
-\lambda \cos \beta_{b}
\end{array}\right)
$$

Ha a (7) egyenletekben a $\lambda$ paraméterre a $v=\lambda \sin \beta_{b} / R_{b}$ lineáris transzformációt alkalmazzuk, a számítások elvégzése után a

$$
\left\{\begin{array}{l}
x_{s}(\varphi, v)=R_{b}(\cos (\varphi-\eta)+v \sin (\varphi-\eta)) \\
y_{s}(\varphi, v)=R_{b}(\sin (\varphi-\eta)-v \cos (\varphi-\eta)) \\
z_{s}(\varphi, v)=p(\varphi-v)
\end{array}\right.
$$

Az (5) és (8) egyenletalakok összevetéséből a következő eredményre jutunk:

$$
\begin{aligned}
& \varphi-\eta=u-\eta+w \\
& w=\varphi-v
\end{aligned}
$$

A két egyenlettípusban a paraméterek geometriai értelmezése különböző. Az (5) egyenletekben az $u$ paraméter az evolvenst lefejtő egyenes alapkörön való legördülésének szöge, a $w$ pedig a teljes, lefejtett evolvens-ívdarab $z$ tengely menti csavarmozgásának paramétere, tehát mindkettő értelmezése szög. Ettől eltérően, a (9) egyenletben a $\varphi$ szög az $S$ generáló egyenest hordozó sík legördülési útját mérő központi szög, míg $v$ az alaphenger és a generáló egyenes $Q$ érintkezési pontjától mért szakasz $x y$ síkra (lényegében az alapkör $P B$ érintőjére) bocsátott vetületének és az alapkörsugárnak az aránya.

A (9) egyenlőségekből kifejezvén a $\varphi$ szöget, a

$$
w+v=w+u \Leftrightarrow v=u
$$

egyenlőséghez jutunk. Ez azonban nem szabad megtévesszen a paraméterek variációs intervallumának meghatározásakor, ugyanis az (5) felírás esetében az $u$ paraméter változása csupán az alapsíkbeli evolvensív hosszát befolyásolja, míg a $v$ a (8) alakban az evolvensív hosszát és ennek $x y$ sík feletti magasságát is befolyásolja.

Mindkét esetben a fogoldal evolvens csavarfelületének vezérgörbéje az alaphengerre illeszkedő, $\beta_{b}$ dőlésszögű csavarvonal. A generáló görbék viszont különböznek. Első esetben a felület generáló görbéje az $x y$ síkban definiált evolvens, melyet az alap- és fejkörök között értelmezünk. A második esetben a generáló görbe az $S$ síkba illeszkedő, az alaphenger generátorával $\beta_{b}$ szöget bezáró egyenes.

A parametrikus reprezentáció, illetve a pontfelhő előállítása során fontos, hogy egyenlő - vagy minél egyenletesebb - sürüségű pontfelhőt hoz- zunk létre [10]. Első esetben az evolvens ívdarab egyenlő hosszúságú ívszakaszokra való felosztása, illetve a csavarvonalon való elmozdítás $w$ szögparaméterének egyenletes felosztása jelenti a megoldást. Ismert tény, hogy ha az alapkörön legördülő egyenes figyelembe vett érintési pontjai egyenlő hosszúságú köríveket határoznak meg, akkor a megfelelő evolvensívek hossza mértani sorozatot alkot [5]. A (4) egyenletekből felírható az evolvens elemi ívhossza:

$$
\mathrm{d} s=R_{h} u \mathrm{~d} u
$$

Ha az $u$ paraméter-intervalluma $\left[u_{1}, u_{2}\right]$, a megfelelő ívhossz

$$
s_{i, i+1}=\int_{u_{i}}^{u_{i+1}} \mathrm{~d} s=\frac{1}{2} R_{b}\left(u_{i+1}^{2}-u_{i}^{2}\right)
$$

Az alapkör és a fejkör között elterülő evolvensív hossza

$$
L=\frac{1}{2} \sqrt{R_{a}^{2}-R_{b}^{2}},
$$

vagyis a legördülő egyenes szakasz hosszának a felével egyenlő.

Az íven felvett $N$ pont $N$-1 ívszakaszt határoz meg, melyek hossza

$$
\Delta L=L /(N-1)
$$

A (12) és (14) képletek összevetésével kapjuk az egyenletes felosztáshoz szükséges $u$ paramétersor rekurzív relációját:

$$
u_{i+1}=\sqrt{\frac{2 \Delta L}{R_{b}}+u_{i}^{2}}
$$

A második esetben az egyenletes pontsűrüség elérésére mindkét paraméter eloszlása egyenetlen kell hogy legyen. A paraméterek rekurzív függvénye ez esetben igen bonyolult lesz.

Matematikai szempontból a (8) alak sokkal előnyösebb, mint az (5) egyenletek, ugyanis az előbbiben a koordináták független $\varphi$ és $v$ paraméterei szét vannak választva, ennélfogva az élgörbe analitikusan kifejezhető.

\subsection{A homlokfelület}

A homlokfelület (2. ábra) egyenleteit parametrikusan kétféleképpen lehet kifejezni:

-a $V$ pontból kiinduló sugársor alapján;

- az xy síkkal párhuzamos síkokban illeszkedő körök alapján.

A sugársor a $V\left(0,0, h_{0}\right)$ pontból indul.

Legyen az $u$ paraméter a $V$ csúcsból a generátoron illeszkedő $M$ futópontig mért távolság, $\nu$ pedig a generátor vetülete és az $x$ tengely által bezárt szög. 


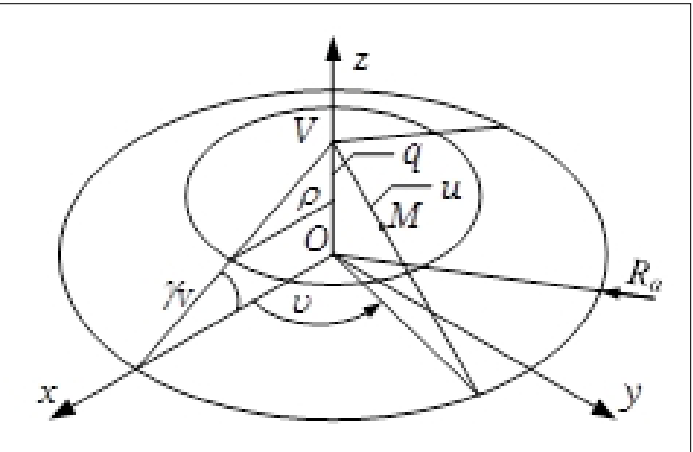

2. ábra. A kúpfelület parametrizálása

Ez esetben

$$
\begin{aligned}
& x_{s}(u, v)=u \cos \gamma_{V} \cos v \\
& y_{s}(u, v)=u \cos \gamma_{V} \sin v \\
& z_{s}(u, v)=R_{a} \operatorname{tg} \gamma_{v}-u \sin \gamma_{V}+\delta_{H}
\end{aligned}
$$

A metszőkerék élezése következtében a homlokfelület a $z$ tengely pozitív irányításában $\delta_{H}$ értékkel csúszik el.

Ha a kúpfelületet körseregként kezeljük, akkor a független paraméterek a futókör $\rho$ sugara és az $v$ polárszög. Ebben az esetben a parametrikus egyenletek alakja a következő lesz:

$$
\begin{aligned}
& x_{s}(\rho, v)=\rho \cos v \\
& y_{s}(\rho, v)=\rho \sin v \\
& z_{s}(\rho, v)=\left(R_{a}-\rho\right) \operatorname{tg} \gamma_{V}+\delta_{H}
\end{aligned}
$$

Ha paraméterként a polárszöget és a $q$ csúcsból mért távolságot választjuk, akkor a (17) egyenletek a következő alakot öltik:

$$
\begin{aligned}
& x_{s}(q, v)=q \operatorname{ctg} \gamma_{V} \cos v \\
& y_{s}(q, v)=q \operatorname{ctg} \gamma_{V} \sin v \\
& z_{s}(q, v)=R_{a} \operatorname{tg} \gamma_{V}+\delta_{H}-q
\end{aligned}
$$

A (16), (17) és (18) parametrikus egyenletekből ugyanazon implicit alakra jutunk:

$$
x_{s}^{2}+y_{s}^{2}-\left(\left(R_{a}-\rho\right) \operatorname{tg} \gamma_{V}+\delta_{H}\right)^{2} \operatorname{ctg}^{2} \gamma_{V}=0
$$

\section{Az oldalél egyenletei}

Az oldalél a fog hátfelülete és a homlokfelület metszésvonala. Ennek két szakasza van:

-az evolvens csavarfelületből származó élszakasz;

- a foglábfelületből származó élszakasz.

Az utóbbi szakaszt csak az alámetszés határa fölött vesszük tekintetbe. Az alámetszés határa közelében e szakasz jelentős, és ismeretes, hogy az idetartozó evolvensszakaszt elrejti, tehát a lefejtés során a megmunkált fog fejét lenyesi. Jelen közleményben ezt a részt nem elemezzük.

\subsection{A kúp parametrikus egyenleteinek hasz- nálata}

Tekintsük a (8) és (16) parametrikus egyenleteket. Az oldalél koordináta-függvényeit a megfelelő felület-koordináta-függvények egyenlővé tételéből nyert, három egyenletből álló, négyismeretlenes egyenletrendszerből kinyert paraméter kapcsolat segítségével fejezzük ki:

$$
\begin{aligned}
& x_{s}(\varphi, v)=x_{s}(u, v) \\
& y_{s}(\varphi, v)=y_{s}(u, v) \\
& z_{s}(\varphi, v)=z_{s}(u, v)
\end{aligned}
$$

A (20) egyenletrendszerrel ekvivalens egyenletrendszert nyerünk, az alábbi módon:

$$
\begin{aligned}
& \left(a^{\prime}\right) \leftarrow(a)^{2}+(b)^{2} \\
& \left(b^{\prime}\right) \leftarrow(b) /(a) \\
& \left(c^{\prime}\right) \leftarrow(c)
\end{aligned}
$$

A számítások elvégzése után kapjuk az alábbi ekvivalens rendszert:

$$
\begin{aligned}
& R_{b}^{2}\left(1+v^{2}\right)=u^{2} \cos ^{2} \gamma_{V} \\
& v=\varphi-\eta-\operatorname{arctg} v \\
& p \varphi-p v=R_{a} \operatorname{tg} \gamma_{V}+\delta_{H} u \sin ^{2} \gamma_{V}
\end{aligned}
$$

Ebből kifejezhető a kúpfelület független paraméterei közötti összefüggés:

$$
\begin{aligned}
v(u) & =\left(R_{a} \operatorname{tg} \gamma_{V}+\delta_{H}-u \sin \gamma_{V}\right) p^{-1}-\eta+ \\
& +\operatorname{inv}\left(\operatorname{arctg} \sqrt{\frac{u^{2} \cos ^{2} \gamma_{V}}{R_{b}^{2}}-1}\right)
\end{aligned}
$$

A kúpfelület független paraméterei közötti kapcsolat második változatát a (8) és (17) egyenletek együttes vizsgálatából nyerjük. A koordináta-függvények kiegyenlítéséből kapott egyenletrendszert a (21) relációk szerint alakítjuk át, és a számítások után a következő egyszerübb alakra jutunk:

$$
\begin{aligned}
v(\rho)= & \frac{\left(R_{a}-\rho\right) \operatorname{tg} \gamma_{V}+\delta_{H}}{p}-\eta+ \\
& +\operatorname{inv}\left(\operatorname{arctg} \sqrt{\frac{\rho^{2}}{R_{b}^{2}}}\right)
\end{aligned}
$$

A (23) és (24) függvények ekvivalensek, ami könnyen igazolható azáltal, hogy az előbbiben a $\rho=u \cos \gamma_{V}$ változócserét hajtjuk végre. 
Az evolvens csavarfelület paraméterei közötti összefüggést a (8) és (19) egyenletekből kapjuk. Behelyettesítve a kúpfelület (19) implicit alakjába a fogoldal evolvens csavarfelületének (8) parametrikus koordináta-függvényeit, a következő függvényt kapjuk:

$$
\varphi(v)=\frac{R_{a} \operatorname{tg} \gamma_{V}+\delta_{H}}{p}+v \frac{R_{b}}{p} \operatorname{tg} \gamma_{V} \sqrt{1+v^{2}}
$$

\section{Az élpont-koordináták pontossága}

Az élpont koordinátáit, figyelembe véve az előbbiekben feltüntetett megoldási lehetőségeket, kétfeleképpen számíthatjuk ki:

- a homlokkúp parametrikus egyenleteiből; - a fogoldal parametrikus egyenleteiből.

A pontosságot az élgörbét adó két felület implicit egyenleteibe való behelyettesítés hibájával definiáljuk.

A csavarevolvens implicit egyenletét ennek a (8) koordináta-függvényeiből állítjuk elő. Egyszerű számítások után az alábbi kifejezésre jutunk:

$$
\begin{aligned}
& G(x, y, z): \frac{y}{x}-\operatorname{tg}\left(\frac{z}{p}-\eta+\sqrt{\frac{x^{2}+y^{2}}{R_{b}^{2}}-1}\right)- \\
& \operatorname{arctg} \sqrt{\frac{x^{2}+y^{2}}{R_{b}^{2}}-1}=0
\end{aligned}
$$

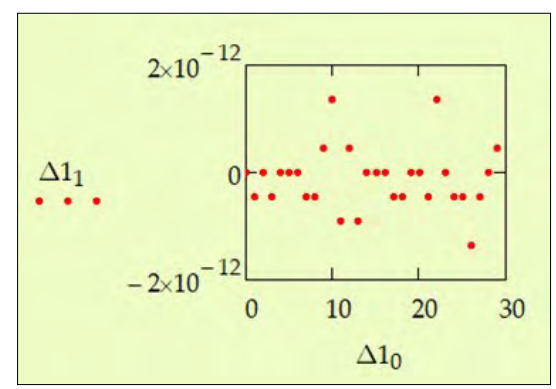

3. ábra. A kúpfelület implicit egyenletébe való behelyettesítés hibaeloszlása

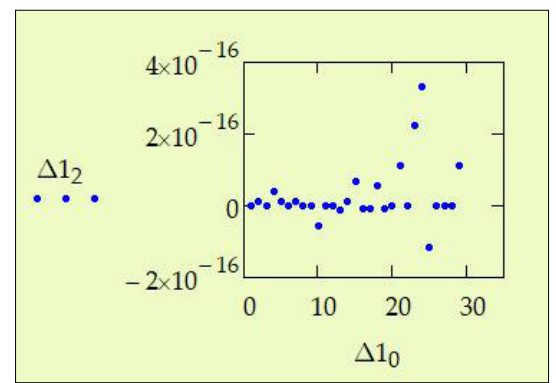

4. ábra. Az evolvens csavarfelület implicit egyenletébe való behelyettesítés hibaeloszlása
A számításokat egy $z_{s}=21$ fogú, $m_{n}=5 \mathrm{~mm}$ modulú és $\alpha_{0}=20^{\circ}$ elméleti lécprofilszögű metszőkerékre végeztük el, melynek csúcshomlokszöge $\gamma_{\mathrm{v}}=5^{\circ}$ és csúcshátszöge $\alpha_{\mathrm{v}}=6^{\circ}$. A metszőkereket új állapotában elemezzük, így legnagyobb profileltolása, $\delta=0,021$ fajlagos működési hézag (JIS-B1705-1973) és $\mathrm{s}_{\mathrm{a}}=1,3 \mathrm{~mm}$ fogfejvastagság mellett $\xi_{1}=+0,235$.

\subsection{A kúpfelületből nyert paraméter-kap- csolat hibája}

Vizsgáljuk a kúpfelület független paraméterei közötti függvénykapcsolattal számított élkoordinátákat. Ez azt jelenti, hogy a (23) függvényt a (16) parametrikus egyenletekbe helyettesítjük. Az élpontok száma $N=30$.

Ha a kapott élkoordinátákat a kúp implicit egyenletébe helyettesítjük, a 3. ábrán látható hibaeloszlást kapjuk.

Ha ugyanazokat a koordinátákat az evolvens csavarfelület implicit egyenletébe helyettesítjük, meglepő módon sokkal kisebb hibát kapunk (4. ábra).

\subsection{Az evolvens csavarfelületből nyert paraméter-kapcsolat hibája}

Az evolvens csavarfelület független paraméterei közötti (25) függvénykapcsolatot helyettesítjük be a (8) paraméterfüggvényekbe. Az így számított

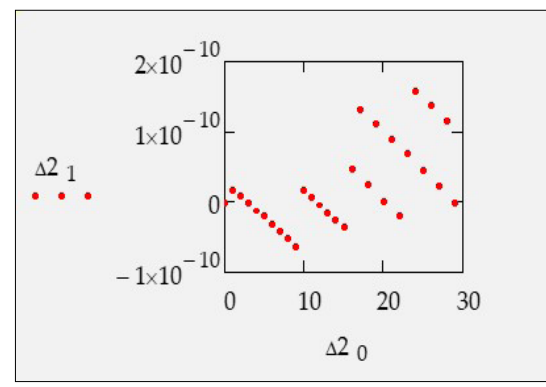

5. ábra. A kúpfelület implicit egyenletébe való behelyettesités hibaeloszlása

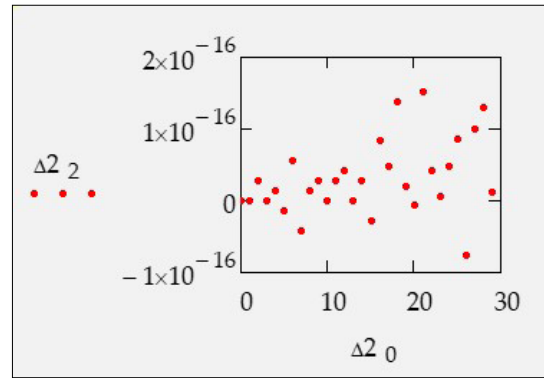

6. ábra. Az evolvens csavarfelület implicit egyenletébe való behelyettesítés hibaeloszlása 
koordinátákat először a (19), majd a (26) implicit függvényekbe helyettesítjük. A hibaeloszlásokat az 5. és a 6. ábrákon tüntettük fel.

Észre lehet venni, hogy a kúpfelület implicit egyenletébe való visszahelyettesítés hibája bizonyos periodicitást mutat, míg az evolvens parametrikus egyenletébe való behelyettesítéssel kapott hibaeloszlás felhőszerü.

\section{Következtetések}

A 3-6. ábrák összehasonlítása alapján megfogalmazhatók az alábbi következtetések:

A kúpfelületről kifejezett élkoordináták 100-szor kisebb hibával elégítik ki a kúpfelület implicit egyenletét, mint a csavarfelületről kifejezett élkoordináták.

A kúpfelületről kifejezett és az evolvens csavarfelületről kifejezett élkoordináták közel azonos pontossággal elégítik ki az evolvens csavarfelület egyenletét.

A kúpfelületről származó élfüggvények egyszerűbb alakúak, ami a valós származtatófelületek egyszerübb alakját eredményezik.

A következtetésnek csupán elméleti értéke van, mert a hiba nagysága 10E9-szer kisebb, mint a legkisebb gyártási tűrésmező.

\section{Köszönetnyilvánítás}

Jelen munka a 4038/24/2018/HTMT szerződésszámú Domus-Egyéni kutatási ösztöndíjtámogatás segítségével valósult meg.

\section{Szakirodalmi hivatkozások}

[1] Radzevich P. S.: Dudley's Handbook of Practical Gear Design. CRC-Press, London, 2016. 368-379.

[2] Radzevich P. S.: Gear Cutting Tools. Fundamentals of design and computation, CRC-Press, London, 2010.

[3] Hollanda D.: Așchiere și scule. Reprografia I.I.S. Tg. Mureș, 1994. 234-240.

[4] Máté M.: Hengeres fogaskerekek gyártószerszámai. Erdélyi Múzeum-Egyesület, Kolozsvár, 2016. 133-158.

[5] Szeniczei L.: Az általános fogazás. Nehézipari Műszaki Könyvkiadó, Budapest, 1958. 49-50.

[6] Dudiță Fl., Diaconescu D.: Mecanisme. Fascicula 2. Reprografia Universității din Brașov, 1983.

[7] Dudás I.: The Theory and Practice of Gear Worm Drives. Penton Press, London, 2000.

[8] Gyenge Cs.: Lefejtőmarók oldalhátszögének pontos meghatározása és optimálása. Gép, 48/10. (1996) 38-40.

[9] Máté M., Kántor A. E., Laczkó-Benedek B.: Metszőkerékkel lefejtett fogaskerekek profilpontosságának vizsgálata. In: XII. FMTÜ Nemzetközi Tudományos Konferencia kiadványa. Kolozsvár, Románia, Műszaki Tudományos Közlemények 7. 279-283.

https://eda.eme.ro/handle/10598/29833.

[10] Tolvaly-Roșca F., Máté M., Forgó Z., Kakucs A.: Development of Helical Teethed Involute Gear Meshed with a Multi-Edge Cutting Tool Using a Mixed Gear Teeth Modeling Method. Procedia Engineering 181. (2017) 153-158.

https://doi.org/10.1016/j.proeng.2017.02.421 